\title{
Birleşik sözcüklerde vurgunun (ölçülebilir) görünümleri
}

\section{Gönül ERDEM NAS1}

\begin{abstract}
APA: Erdem Nas, G. (2019). Birleşik sözcüklerde vurgunun (ölçülebilir) görünümleri. RumeliDE Dil
\end{abstract} ve Edebiyat Araştırmaları Dergisi, (16), 665-676. DOI: 10.29000/rumelide.619687

\section{Özet}

Vurgu, temelde bir seslem üzerindeki soluk baskısı olarak nitelendirilmektedir. Bununla ilgili teorik çalışmalar da bu tanımı destekler nitelikler taşımaktadır. Bununla birlikte teknolojinin gelişmesi sesbilim alanındaki tanımların ölçülebilir olmasını da sağlamıştır. Ses analiz programlarının alınan seslerin ses yazımı ya da spektrogram görüntüsünü sağlaması bu alanda çalışanlar için görülür bir veri sunmaktadır. Bürün ögeleri içerisinde ölçümü en zor olan vurgunun yine henüz tam anlamıla görüş birliği bulunmayan birleşik sözcüklerdeki görünümleri çalışmanın konusunu oluşturmaktadır. Türkçede birleşik sözcükler: sözcük öbeği, bileşik sözcükler gibi adlarla da anılmaktadır. Çalışmada Türkçede sıklıkla kullanılan ve üzerinde daha önce de metrik (ölçülebilir) çalışma yapılmamış birleşik sözcüklerinseslendirilmesi, farklı yaş ve cinsiyete sahip anadili konuşurlarından ses laboratuvarında alınmıştır. Kayıt altına alınan bu sözcükler, cümleye bağımlı ve bağımsız olarakiki şekilde alınmıştır. Böylelikle amaç konuşurun bu sözcükleri sadece sentaktik bir düzlemde aynı şekilde semantik bir bütünlükle ortaya çıkarıp çıkarmadığını çalışmada değerlendirmektir. Alınan bu ses kayıtları yine laboratuvar ortamında vurgu görünümleri esasında Praat ses analiz programında değerlendirilmiştir. Çıkan sonuçlara göre bir sözcük öbeğinin birleşik sözcük olarak değerlendirilmesi için esas oluşturan fonolojik, sentaktik ve semantik birlikteliğin vurgu bakımından görünümü de değerlendirilmiştir. Sentaktik yapı içerisindeki birleşik sözcüğün tek başına semantik olarak söylenmesi vurgun yerini değişitirip değiştirmemesi çalışmada incelenmektedir. Çalışma, ölçülebilir vurgulara ait görünümleri (spektorgramları) uygulamalı bir çalışma içerisinde incelemektedir.

Anahtar kelimeler: Vurgu, birleşik sözcükler, ölçülebilir vurgu.

\section{Views of emphasis (measurable) in compound words}

\begin{abstract}
Word stress is basically defined as a pale pressure on a vowel. The theoretical studies related to the this subject support the definition. However, the development of technology has made the definitions in the field of phonology measurable. The fact that voice analysis programs provide sound writing or spectrogram image of the received sounds provides visible data for those interested in this field. The subject of the study is the appearance of the most difficult word stress which is not yet fully understood in the prosodic elements. In Turkish composite words are referred by phrases, compound words etc. In the study, the vocalization of the compound words which are frequently used in Turkish and have not been metricly measured before, were taken from the native speakers of different ages and genders in a voice laboratory. These words were recorded in two ways, independent and dependent of sentence. Thus, the aim of this study is to evaluate whether or not the speaker produces these words on a syntactic plane in the same way with a semantic integrity. These sound recordings
\end{abstract}

1 Dr. Öğr. Üyesi, Bartın Üniversitesi, Edebiyat Fakültesi, Dilbilim Bölümü (Bartın, Türkiye), gonulerdem2002@yahoo.com, ORCID ID: oooo-0001-8100-3884 [Makale kaylt tarihi: 21.08.2019-kabul tarihi: 20.09.2019; DOI: 10.2900o/rumelide.619687] 


\begin{abstract}
were again evaluated in the Praat sound analysis program on the basis of word accent views in a laboratory condiditons. According to the results, the appearance of phonological, syntactic and semantic association which is the basis for evaluating a phrase as a compound word was also evaluated in terms of emphasis. The semantic singing of the unified word in the syntactic structure is examined in the study. The study examines the views (spectrograms) of measurable word accent from a theoritical aspect and their status in an applied one.
\end{abstract}

Keywords: Stress, compundwords, metricalstress.

\title{
Giriş
}

Vurgu, dildeki bürün ögeleri içerisinde üzerinde en çok tartışllan konudur. Vurgunun oluşumu konusundaki tanımlarda ise bir bütünlük bulunmaktadır. Vurgunun oluşumu, konuşma esnasında bir seslem üzerindeki soluk baskısı olarak ifade edilir. Vurgu tek başına seslem üzerindeki soluk baskısıyla oluşmamakla birlikte bu soluk baskısının o seslem üzerindeki süresinin uzamasıyla da anlaşılır bir bütünlük oluşturulur. Böylelikle dinleyici için bu bütünlükle oluşturulan seslem, sözcük içerisinde ayırt edici bir özellik kazanmasını sağlar.

Vurgu, sesbilimcilerin görüşlerine göre sesin akustiğinden çok ses organlarının hareketleriyle oluşmaktadır. Bu hareket kimilerine göre gırtlak altındaki basınçla, kimilerine göre karın kaslarındaki basınçla, kimilerine göre ise solunum kaslarının hareketleriyle oluşmaktadır. Demircan ise tüm bu görüşlerden hareketle fizyolojik açıdan vurgulu heceyi: vurgu atışı (stres pulse) ile güçlendirilmiş bir göğüz atışı (chestpulse) ve dinleyen açısından ise (loudness) ses yüksekliği olarak iki türlü tanımlamaktadır. Vurgulu heceye daha fazla hava basıncı uygulanmasıyla dinleyicinin kulak zarına belli genliklerde titreşimler gönderilir, bunlar o hecenin ya yüksek/güçlü, ya da alçak/zayıf duyulmasını sağlar.

Vurgu algılanması:

1. Sesbirimlerin göreceli uzunluğuna

2. Seslerin görece şiddetine

3. Temel titreşim sayısı (frekans) ve izgeye (spectrum) dayanmaktadır (2015:125).

Anlam ayırıcı olma temel özelliğini taşıyan parçalarüstü sesbirimler, her dilde var olmalarına karşın, dillerdeki yapılanma gereği karşıtlı ilişkisi içinde yer almıyorlarsa bürünbirim (prosedeme) olma özelliği de taşımazlar. Söz gelimi, sözcük vurgusu, kimi dillerde yenilik (newness), karşıtllk(contrast), bilgilendiricilik (informativeness) ve odak (focus) gibi anlam ayırt edici işlevleri üstlenirken, kimi diller için bu durum geçerli değildir. Örneğin, Fransızca, Macarca, Fince ve Çekçe gibi dillerde vurgunun yeri değişmezken, İtalyanca, İspanyolca, Türkçe ve İngilizce gibi dillerde vurgu, anlam ayırt edicidir ve bürünbirim olma özelliği taşır (Ergenç 2002: 25).

Türkçedeki vurgu sözcüklerde anlam ayırıcı niteliğe sahiptir. Vurgu kök ve eklerde farklllık göstermektedir. Tek seslemli sözcüklerde vurgu o seslemde bulunurken sözcük ek aldıkça vurgunun yeri de değişmektedir. Kök sözcük iki veya daha fazla seslemden oluşabilmekte, sözcük Türkçe veya alıntı olunca da vurgu farklılık gösterebilmektedir. Demircan kök vurgusunu: 
a. Vurgusu sonda olanlar

b. Vurgusu sonda olmayanlar (Vurgusu sondan bir önceki hecede olanlar, diğerleri) şeklinde sınıflandırmış ve o dönem TDK tarafından çıkarılan Türkçe Sözlük esasıyla bu şekildeki kök sözcüklerin sayısal verisini vererek incelemiştir (1975:285).

Ses analiz programlarıyla alınan kayıtlarda elde edilen verilerin ışığında vurgunun Türkçede sabit bir görüntü vermediği görülmektedir. Son seslem vurgusu gerçekliği her zaman ve her sözcük yapısı için sesprogramları verilerinde bir bütünlük oluşturmamaktadır. Bu konuda program destekli çalışmalar lisansüstü olarak bulunmaktadır. Çalışmanın konusunu oluşturan birleşik sözcük vurgusu, vurgu konusu içerisinde belki de en karmaşık olanıdır. Birleşik ya da bileşik sözcükler daha adlandırılmasından oluşum şekline kadar tam bir görüş ortaklığı bulunmayan konular içerisindedir.

Birden fazla seslemden oluşan sözcüklerde yine birden fazla vurgu bulunabilir. Bunlar asıl vurgu yani birincil vurgu, ikincil vurgu ve bazen zayıf olmakla birlikte üçüncül vurgudur. Türkçe sözcüklerde eklenme sırasında vurgunun daima son ek üzerinde yoğunlaştığı üzerinde durulmaktadır. Ama bu tüm ekler için geçerli değildir. Bazı eklerin vurguyu üzerine almadığı da bir gerçektir.

Dilimizde son seslem vurgusu ana kuralının dışında vurgulanan sözcükler de oldukça fazladır. Vurgusuz son ek dışında birçok Türkçe ve alıntı sözcükte vurgu bir önceki ya da en baştaki seslemde bulunabilir. Son seslemde bulunmayan vurguya gerilek vurgu denilmektedir (Banguoğlu, 1959:182).

\section{Ölçülebilir vurgu}

Stetson (1928) konuşma eyleminin prosodik organizasyonunun doğrudan nefes vermeyi kontrol eden kaslara yansıdığını düşünmekteydi. Kabaca ifade etme gerekirse Stetson bir sözcedeki her heceyle eş zamanlı bir nefes vuruşunun olduğunu ve nefes vuruşunu da göğüs kafesinde ortaya çıkan ve hecenin zirve (peak) noktasına hece sınırının segmentini aşan titreşimi veren kasılma olarak tanımlamaktadır. Dahası, Stetson vurgulu hecelerin diğerlerinden uzun bir nefes vuruşu taşıdığını, bunu yapanın da göğüs kafesi değil karın boşluğu olduğunu düşünmektedir. Tabii çalışmanın öncü olması ve üzerine yapılan çalışmalarda uygulamanın çok olmasıyla birlikte bu görüşe karşıt görüşler bulunmaktadır. Bu araştırmacıların yaptı̆̆ı deneylerde denekler vurgulu hecelerin sadece bazılarında (özellikle karşıtsal odak olanlarda) nefes vuruşu ürettiğini göstermiştir. Yani, diğer ölçütlerle vurgulu olarak sınıflandırılan bazı heceler nefes vuruşu almamaktadır.Peterson normal gırtlak kontrolünü yapabilen ancak cihazla solunum yapmak zorunda olan bir felçli hastanın durumunu rapor etmektedir. Bu hasta "güçlü vurgulara sahip bir konuşma üretemese de her açıdan normal konuşma şekline yakın bir konuşma üretebilmektedir." Görünüşe göre nefes vuruşu normal konuşma için şart değildir (1958: 402-4). Yukarıdaki araştırmalardan şu sonuç çıkmaktadır: eğer nefes baskısı varsa vurgunun olması muhtemeldir ancak nefes baskısı olmadan üretilen vurgulu heceler de bulunmaktadır (Hayes, 1995: 67).

Dillerin süre ve perdeyi kendi fonolojik sistemlerinde tamamen farklı amaçlarla kullandığı düşünüldüğünde vurgunun birden fazla özellikle ilgili olmasının ve yüksekliğin beklenenden daha az etkili olmasının oldukça ilginç olduğu anlaşılacaktır. Süre, birçok dilde sesbirimsel bir özellik olan ünlü uzunluğuyla ilgilidir. Aynı zamanda fonolojik öbeklenmeyi de belirlemek için kullanılır yani majör öbeklerin sonu tipik olarak fazladan bir süre alır (Klatt 1975; Wightman et al. 1992). Ayrıca perde, sesbirimsel ton sistemi olan dillerde ton belirleyicisi ve ezginin fonetik temelidir. Bütün bunların anlamı 
ise şudur: yüksekliğin küçük etkisini bir yana koyarsak başka fonolojik amaçlara hizmet eden fonetik kaynakları kullandığı için vurgu fonolojik bir parazittir(Akt. Hayes, 1995: 100).

Ölçülebilir vurgu teorisi vurgunun dillerdeki görünümlerini veya oluşumlarını sadece soluk baskısıyla değerlendirmenin yanlış olduğu görüşünden hareket etmektedir. Bu görüşe göre fonolojik dizgede vurgunun oluşumu veya seslemdeki görünüşü süre, perde, ezgi gibi diğer bürün ögelerinin ölçümdeki etkisine de bağlıdır. Praat gibi ses analiz programlarında ses ölçümleri alınırken çıkan görüntü bu görüşü destekler niteliktedir. Vurguyu gösteren eğri ile yeğinliği (intensity) gösteren eğrilerin aynı seslem üzerinde yükseldiği ve bu seslemin de süre bakımından daha uzun olduğu görülmüştür.

Seslendirme esnasında doğal olarak, bazı fonetik özellikler diğerlerinden daha çok ön plana çıkmaktadır. Güçlü ritmik vuruşların nefes vuruşuyla, daha uzun süreyle ve yükselen perdeyle üst üste gelmesi oldukça normaldir. Ancak bunlar sadece eğilimdir ve fonoloji ritmik yapı dışında başka amaçlara da hizmet ettiği için bu amaçların yerine getirilmesi için ritmik vuruşlarla belli fonolojik olgular arasındaki doğal korelasyon yıkılabilir. Bu da şu gözlemi doğurur: vurgunun ortaya çıkışında genel eğilimler bulunmaktadır ancak bunlar sabit değildir (Hayes, 1995:5-6).

\section{Birleşik sözcük ve vurgusu}

Birleşik sözcükler, iki ya da daha fazla sözcügün bir kavramı karşılamak amacıyla bir araya gelmesi ve bir araya gelirken sözcüklerin anlamının toplamının yanı sıra bileşenlerden birinin ya da her ikisinin birden anlamını yitirerek yeni bir anlama karşıllk gelmesi sonucu ortaya çıkan sözlükselleşmiş yapılardır. Birleşikler tam, yarı ve zayıf olmak üzere üçe ayrılabilir. Tam birleşikler, kimyadaki bileşikler gibi homojendir. Bileşenlerden en az biri kendi özelliğini, anlamını yitirir. Yarı ve ara/zayıf birleşikler ise karışımlar gibidir. Kimi zaman homojen, kimi zaman heterojendir. Bileşenleri, özelliklerini korur. Tam birleşikler, birleşik sözcüğün bileşenlerinin anlambilimsel, sesbilimsel ve biçimbilimsel olarak tam bir kaynaşma içinde olması durumudur. Tam birleşik örneklerinden bazıları şunlardır: hanımeli, aslanağzı, bilgisayar, karaağaç, ayakkabı, kadınbudu, kahvaltı, cumartesi, delikanlı, karabiber, karabasan. Yarı birleşiklerde ise birleşik sözcügü oluşturan bileşenlerde kimi zaman anlam kaybı görülmediği gibi kaynaşmalara da rastlanmaz. Tam birleşiklerden farkı çözümlenebilir ve bağlama göre ögelerinden birinin düşürülebilir olmasıdır. Çamaşır makinesi, duvar saati, çay kaşı̆̆ı, göz kalemi, saç boyası, ayçöreği, beyaz peynir gibi örnekler yarı birleşik olarak kabul edilir. Birleşik sözcükle öbek arasında kalmış olan örnekler ise zayıf birleşikler grubuna girmektedir. Bu tür birleşikler sözlükselleşme sürecine girmiş; ama tam olarak sözlükselleşmemiştir ve kolayca çözümlenebilir. Bu nedenle de tam ve yarı birleşik sözcüklere göre daha karmaşık bir yapıya sahiptir. Öbeklerden ayırt edilmeleri oldukça zordur; çünkü aynı zamanda öbek olarak da kullanılırlar: iç kapak, dış kapak, kitap kapă̆ı, köy yolu, tahta kapı, kahve tabağı gibi (Çürük, 2017: 22-23).

Çok seslemli bu sözcükler üç aşamadaki (anlambilimsel, sesbilimsel ve biçimbilimsel) birleşimlerinin yanı sıra bürünsel olarak vurgu ile de bir bütünlük oluşturmalıdır. Birleşik sözcüklerdeki vurgu için farklı görüşler bulunmaktadır. Birleşik sözcük vurgusunu bir öbek vurgusu olarak ele alan Banguoğlu'na göre Türkçede birleşik kelimelerin vurgusu üreme basit kelimelerin vurgusuna benzemez daima sondan bir önceki seslemde bulunur ve bu sebeple bir gerilek vurgu sayllır. Yalnız bu vurgu tüm birleşik sözcükleri kapsamaz anlamca kaynaşmış birleşik sözcüklerde vurgu son seslemdedir: kumra'l, sekse'n, sütla'ç, bayku'ş gibi (1959:185). 
Çok seslemli kök sözcüklerde iki ayrı vurgu derecesi bulunur, daha yüksek tonla seslemin söylendiği birincil vurgu ve birincil vurgu almayan seslemlerde bulunan zaylf vurgudur. Bileşik ve tamlama yapılarında üçüncül vurgu düzeyi bulunur. Birincil vurgunun ikinci seslemde olduğu kará ve tahta sözcükleri birleşip karátahtà sözcügünü oluşturduğunda ilk sözcükteki birincil vurgu dururken ikinci sözcükteki -tahtà- vurgu zayıf vurgu olarak değişmektedir. Bileşik adlarda birincil vurgu ilk öğededir:

denīzaltı , hanīmeli, Béyoğlu

Bileşik adlara durum ekleri eklendiğinde, sözcüğün vurgu örüntüsü değişmez, birincil vurgu bileşik adın ilk öğesinde kalır (Özsoy,2004:55-56-72).

Bir birliğin bileşik sözcük olması, bir anlamda onun sözlükselleşmesidir:

a. çocùk oyuncağı: (Bu) oyuncak çocuklar içindir.

b. çocùk oyuncağı: Bu iş çocuk oyuncağı kadar önemsizdir.

c. çocùk oyuncağı: Bu iş çocuk oyuncağına benziyor.

Bileşik sözcük sözlüksel bir birim iken "tamlama" sözdizimsel bir birimdir. Tamlama ile bileşik sözcügü: a. Anlam, b. Özneli-öznesizolması,c. Vurgu, d. Ek alma ayırmaktadır. Öznesiz birliklere anlamlarına bakılmaksızın "bileşik sözcük" denilmemelidir. Bu nedenle tamlama (öbek) vurgusuyla bileşik sözcük vurgusu ayrı ayrı incelenmelidir:

buzkıràn: Buzkıràn (gemi) ırmakta ilerliyor.

bùz kıran: bùz kıran (kişi) kardeşimdir

Özneli birleşik sözcüklerde tamlayanın birinci derece vurgulu hecesi birinci derece vurgusu alır. Birleşik sözlükleşmede vurgu değişikliği olmaz. Öznesiz birleşik sözcüklerde son ya da ikinci sözcüğün birinci derece vurgulu hecesi birinci derece vurgusu alır. Yalın yer adlarında vurgu baş heceye doğru sürülürken birçok birleşik yer adlarında bunun tersine sona sürülmesi söz konusudur. Vurgunun başa ya da sona sürülmesi doğrudan doğruya anlam ayrımı ile ilgilidir. Bütün birleşik kişi adlarında vurgunun sonda olması "tamlama” dan kaçış olarak yorumlanmalıdır: Özdem'ir (Yer adı), Özdem'ir (Kişi adı), 'Özdemir (Soyadi) (Demircan, 1977:263-270).

Birleşik sözcüğ̈̈n seslem sayısı ve seslemin yapısı ile vurgunun yeri arasında bir ilişki varsayımı mantıklı gelse de aynı biçimde oluşturulmuş ve aynı seslem yapısına sahip birleşiklerin farklı vurgu biçimleri sergilemesi birleşiğin anlam boyutunun göz ardı edilmesiyle açıklanabilir (Ergenç, 1995:31).

Levi, birleşik sözcüklerin niteleyiciyi ilk bileşenden önce aldığını, ancak belirtili adtamlamalarında her iki unsurdan önce de niteleyici gelebileceğini belirtir. Ayrıca bürünbilime göre Underhill’in de belirttiği üzere birleşik sözcüklerde ilk bileşenvurguyu tutarken, belirtili ad tamlamalarında iki üyede de vurgu vardır (Underhill $\rightarrow$ Levi 2002: 3). Levi, birleşik sözcüklerin tek bir sözcük gibi davrandığını, belirtiliad tamlamalarının ise daha karmaşık bir yapıya sahip olduğunu belirtir.Levi, birleşik sözcüklerin ve öbeklerin farklı davrandığını belirtir (2002: 7).Ayrıca Levi, bu çalışmasında Amerika'da yaşayan İstanbullu 3 kadın, Samsunlu 1erkek konuşurun ses kaydını alarak test yapmıştır. Buna göre iki bileşeni de sonvurguya sahip olan meyve suyu örneğinde vurgu, sadece ilk bileşenin son hecesinde görülmektedir. Levi’nin çalışmasında yer verdiği bir diğer örnek ise çoban salatasıdır. Levi'ye göre ilk sözcükte perde vurgusu (pitchaccent) vardır, ikinci sözcükte ise yoktur(2002: 11-12). Birleşik sözcükler, 
tek bir sözlüksel birim olarak davrandığı için tek bir vurguyasahiptir, öbeklerin ise iki vurgusu vardır (Levi 2002: 10). Ses kaydı sonuçlarına göre ortaya çıkan yukarıdaki görüntüler birleşik sözcüklerdeki vurgunun tek olduğunu gösterir. Örneğin tüm konuşurlar meyve suyunu sesletirken-ve hecesini vurgulamıştır:

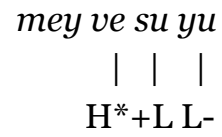

Ancak durum babamın sandalyesi örneğinde farklıdır; çünkü bu yapıyı iki konuşur aşă̆ıda gösterildiği şekilde seslendirmiştir:

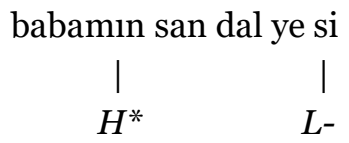

Diğer iki konuşur ise öbeğin tümlecinin ilk hecesi olan -ba’yı, baş ögenin de ilkhecesi olan san-`^ vurgulu söylemiştir:

$$
\begin{array}{ccc}
\multicolumn{3}{c}{\text { babamin san dal ye si }} \\
\mid \text { । } \quad \text { । । } \\
H^{*} H^{-} \quad H^{*}+L & L-(\text { Levi 20O2: 29-3O). }
\end{array}
$$

Levi'nin bu çalışması, birleşik sözcüklerin vurgusunun öbeklerden farkını ortaya koyması açısından önemli taşımaktadır. Sonuç olarak Levi, bu çalışmasında belirtisiz ad tamlaması yapısında olan birleşik sözcüklerin vurgusuyla belirtili ad tamlaması örneklerindeki vurgu farkını ortaya koymuştur. Bu vurgu farkı da $\mathrm{ad}+\mathrm{ad}+(\mathrm{s}) I$ yapısına sahip örneklerin sözlükselleşme sürecinde olduğunu göstermektedir. Vurgu, görüldüğü üzere birleşik sözcükleri öbeklerden ayırt etmeye yardımcı olmaktadır (Akt. Çürük, 2017:52-56).

Birleşik sözcük vurgusu Türkçede tartışmaya açık bir konudur. Birleşik yapıların ses,sözdizim ve anlamca birleşmeleri sıralamalarından bir veya birden fazlası oluşmadığında vurgunun yeri değişmektedir.

\section{Birleşik sözcüklerin vurgu görünümleri}

Çalışma, sık kullanım esasına göre, yazılışı bakımından farklılık gösteren ortalama kırk adet birleşik sözcüğün, yaş ve cinsiyetleri farklı sekiz Türkçe anadil konuşurundan alınan ses kayıtlarının incelenmesi sonucu ortaya çıkan verileri içermektedir. Bu kayıtlar, Bartın Üniversitesi ses laboratuvarında alınan kayıtların Praat ses analiz programında işlenen görüntülerinden oluşmaktadır. Seçilen birleşik sözcüklerin cümle içinde ve cümleden bağımsız iki şekilde kayıtları alınarak konuşurun zihninde anlamca birleşip birleşmediğinin tespit edilmesi amaçlamaktadır. Verilen görüntüler vurgu ve yeğinlik bakımından ortak sonuç veren sözcükler için tek bir görüntü örneğinden hareket etmektedir.

1. İlk görüntü "alabacak” (bir kuş türü) sözcügüne aittir. Sözcük, seslendiren deneklerin bir kısmı tarafından, cümleden bağımsız kullanımda bir kuş türü olduğu bilinmeksizin seslendirilmiştir. Böylelikle kuş türü olduğunu bilen diğer konuşurlarla anlam bakımından birleşik olup olmadığını ölçmek amaçlanmıştır. Çıkan sonuçlar tüm konuşurlar için aynıdır. Aşağıdaki görüntülerden sağdaki 
görüntü sözcüğün spektrogramıdır. Mavi ile gösterilen çizgi vurguyu gösterirken, sarı çizgi yeğinliği göstermektedir. Soldaki görüntü ise sözcüğün sadece vurgu ve yeğinliğini göstermektedir. Buna göre birincil yani asıl vurgu bu sözcük için "-la-" sesleminde bulunmaktadır.
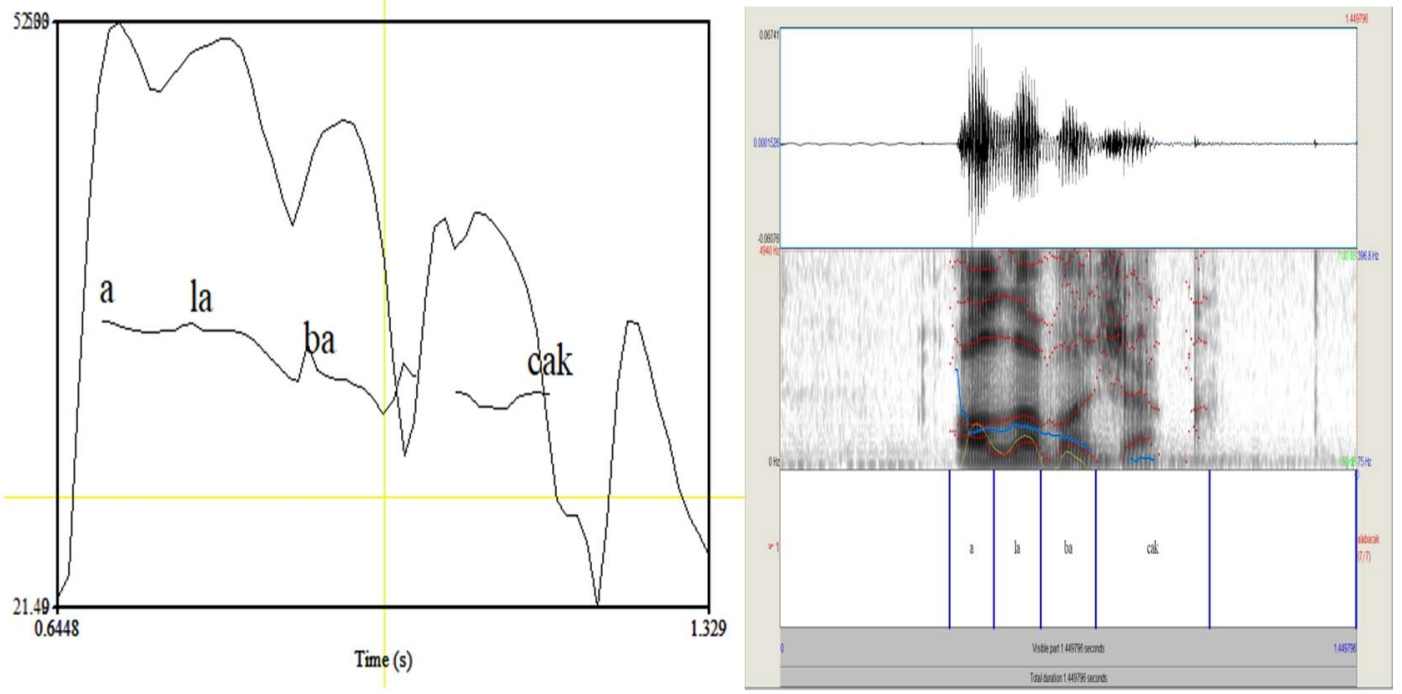

Şekil 1. "Alabacak” birleşik sözcügüne ait vurgu spektrogram görüntüleri

2. Hem tamlama hem de birleşik sözcük olarak kullanılan “ayak üstü” ve "ayaküstü” sözcüklerinin cümle içerisindeki kullanımlarda "ayak üstü morarmıştı" ve "ayaküstü konuştuk" şeklinde kayıtlar alınmıştır. Vurgu görünümlerine bakıldığında soldaki görüntüde tamlama şeklinde kurulan "ayak üstü” sözcük öbeğinde iki vurgu görülmektedir. Birincil vurgu "-yak” sesleminde iken ikincil vurgu “-tü” sesleminde bulunmaktadır. Sağdaki görüntü "Ayaküstü konuştuk” cümlesindeki "ayaküstü” birleşik sözcügüne aittir. Burada tek ve kuvvetli vurgu "-ya" seslemine aittir.
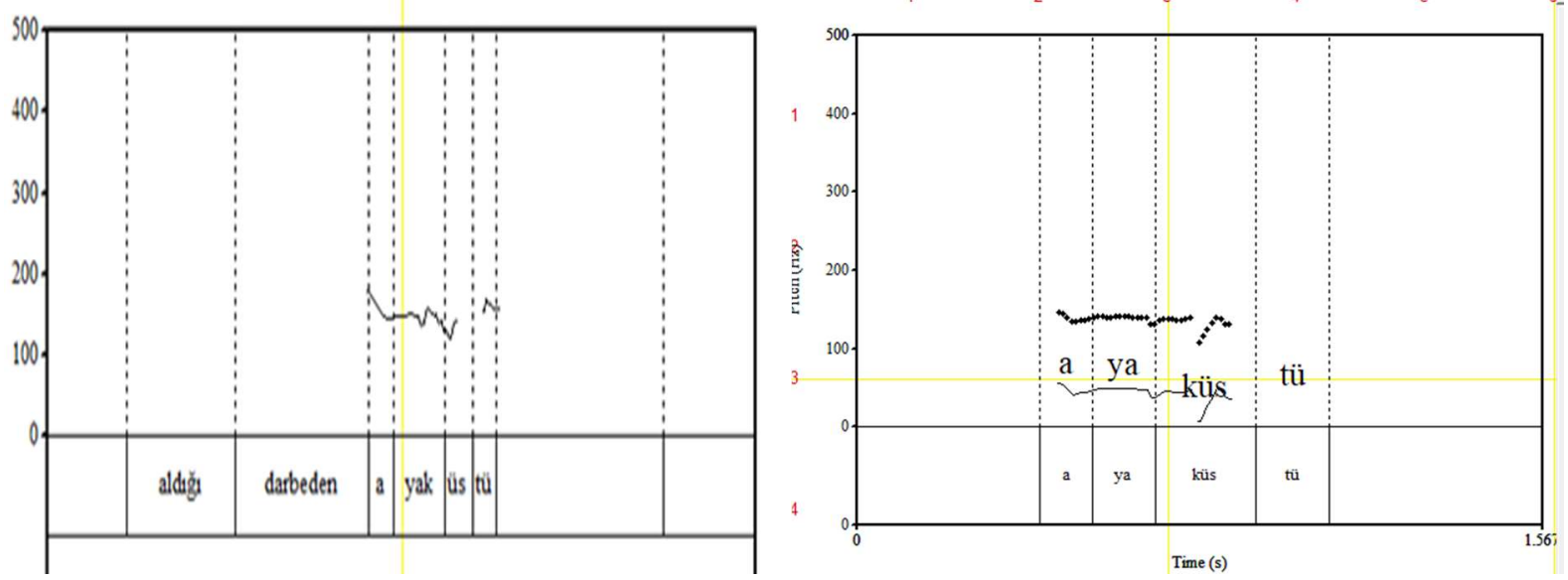

Şekil 2. “Ayak üstü” ve “ayaküstü” sözcüklerine ait vurgu spektrogram görüntüleri

3. Yine hem tamlama hem de birleşik sözcük olarak kullanılan "deniz altı" ve "denizaltı" sözcükleri "deniz altı ayrıntılı inceleniyor" ve "denizaltı çok yol aldı" cümleleri içerisinde değerlendirilmiştir. Bu sözcüklerin bağlam içerisindeki vurgu görünümlerinde "deniz altı” söz öbeğinde "-niz” sesleminde “denizaltı” birleşik sözcüğünde ise “-ni” sesleminde vurgu olduğu görülmüştür. 

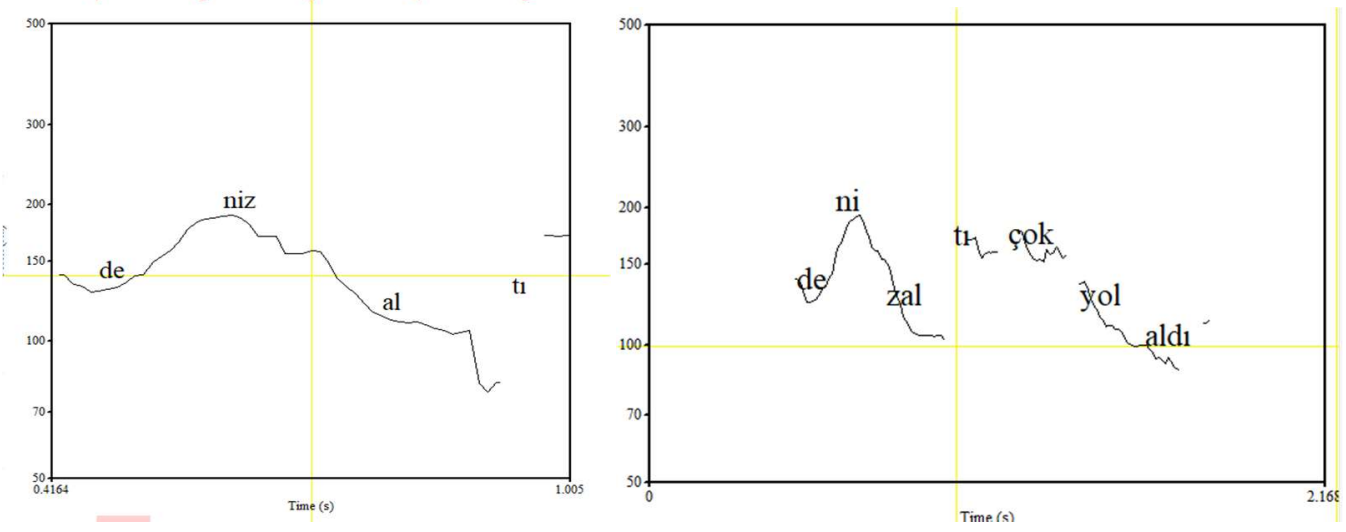

Şekil 3. "Deniz altı” ve “denizaltı” sözcüklerine ait vurgu spektrogram görüntüleri

4. Birleşik sözcük denildiğinde en çok örneğe konu olan sözcükler olan "hanımeli, Çanakkale, birtakım, yaruağzı" gibi sözcüklerin vurgu görünümlerine bakıldığında "hanımeli” sözcüğünde sözcüğün ikinci seslemi olan "-nı" sesleminde, "Çanakkale" sözcüğünde yine ikinci seslem "-nak" a, "birtakım" sözcüğünde "bir-" seslemine, "yavruağzı" sözcüğünde ise ikinci seslem olan "-ru” sesleminde vurgu olduğu görülmüştür.
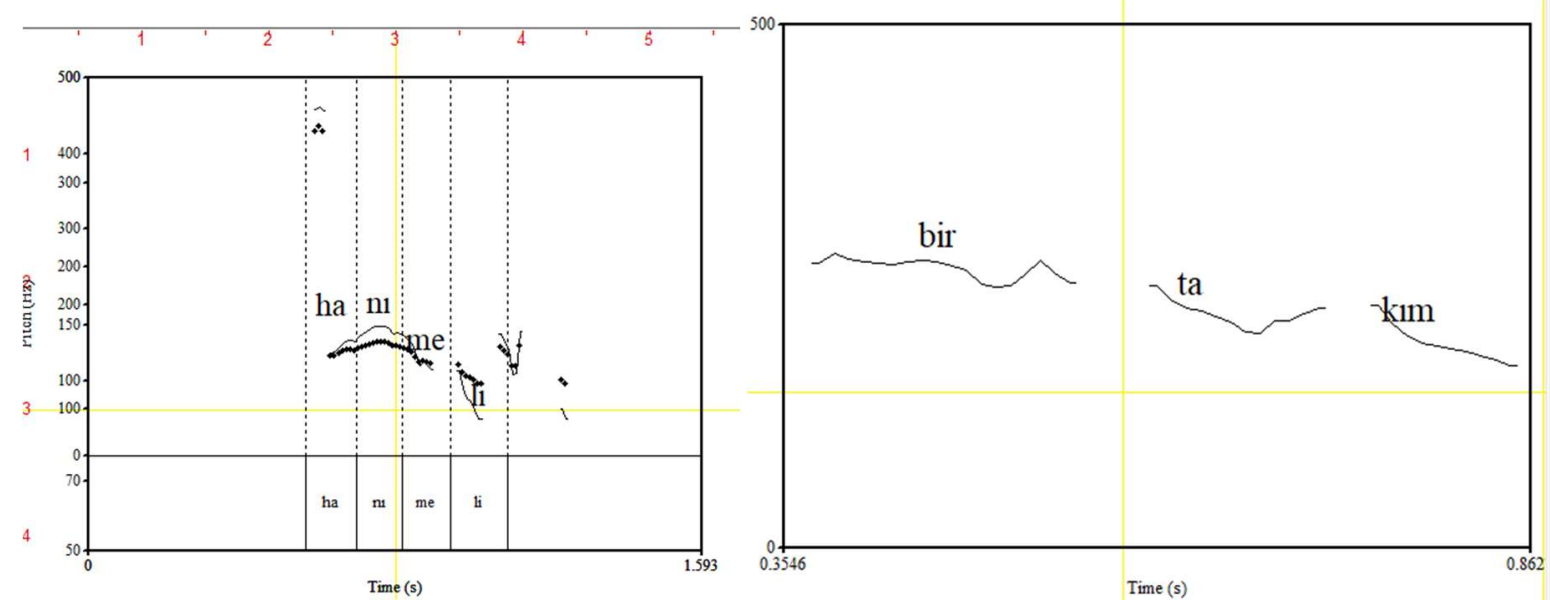

Şekil 4. "hanımeli” ve "birtakım” sözcüklerine aitvurgu spektrogram görüntüleri 

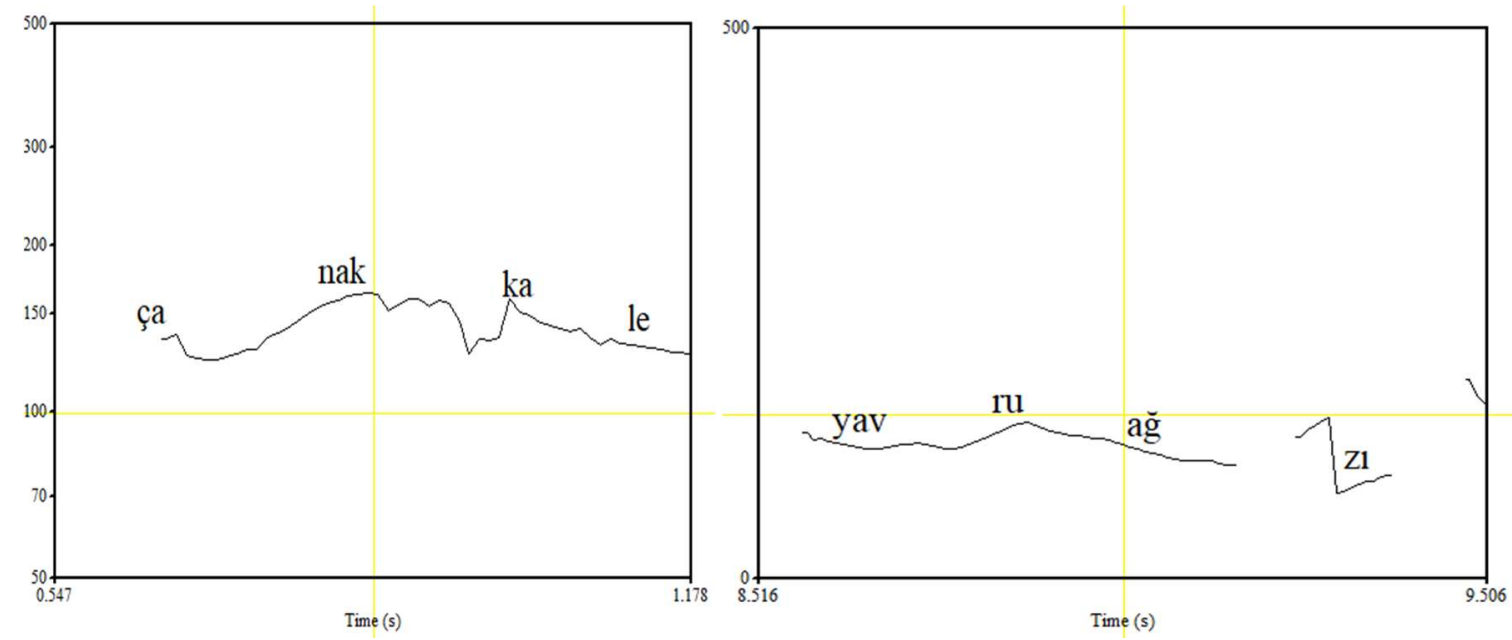

Şekil 5. "Çanakkale” ve “yavruağzı” sözcüklerine ait vurgu spektrogram görüntüleri

5. Anlam bakımından farklılık gösteren birleşik sözcüklerin cümle içerisindeki kullanımları incelendiğinde sonuç daha önce aynı örnekler üzerinde çalışması bulunan Demircan ile bir bütünlük sağlamamaktadır. "Özdemir" sözcüğü için Demircan, yer adı ve kişi adı olarak kullanımında sözcükteki vurgunun son seslem olan "-mir" de olduğunu, soyadı olarak kullanıldı̆̆ında ise "Öz-" sesleminde olduğunu belirtmiştir (1977:272). Sözcüğü yer, kişi adı, ve soyad olarak farklı cümleler içerisinde seslendirdiğimizde; kişi adı olarak "Özdemir Erdoğan yeni şarkısını söyledi”, soyadı olarak "Gül Özdemir sınavı kazanmıştı” ve yer adı olarak "Özdemir Mahallesindeki araç çalınmış” kullandığımızda vurgunun kişi adı ve yer adı kullanımında "-mir” sesleminde, kişi adında ise birincil vurgunun çok az bir değişkeyle "Öz-" sesleminde olduğu tespit edilmiştir.

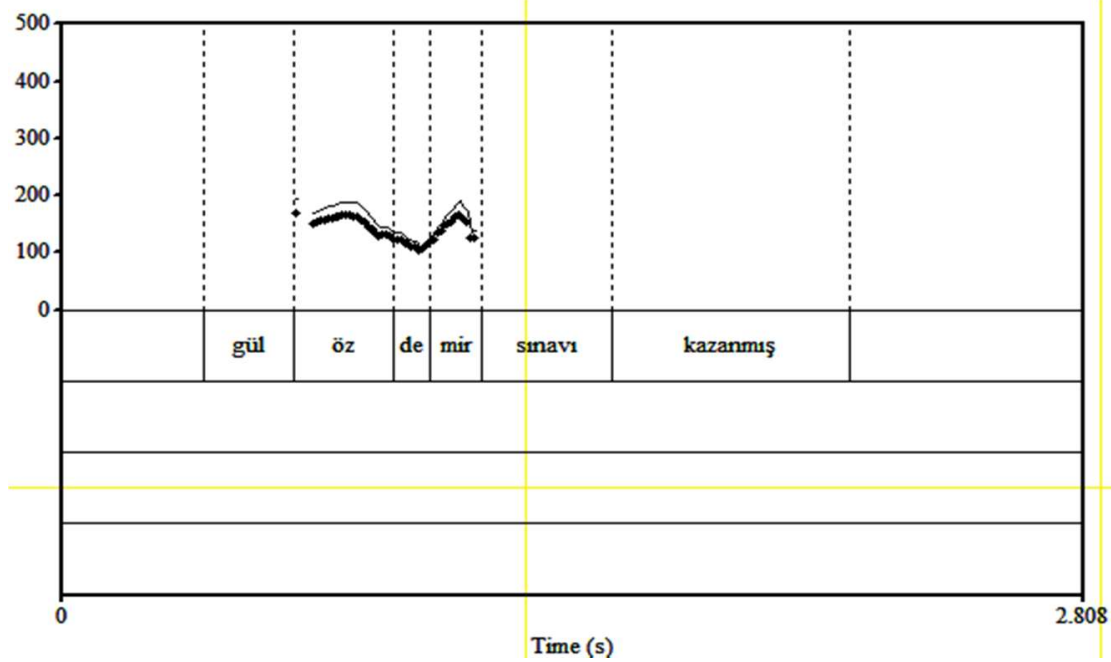

Şekil 6. “Özdemir” sözcüğünün soyadı olarak kullanımına ait vurgu spektrogramı görüntüsü 


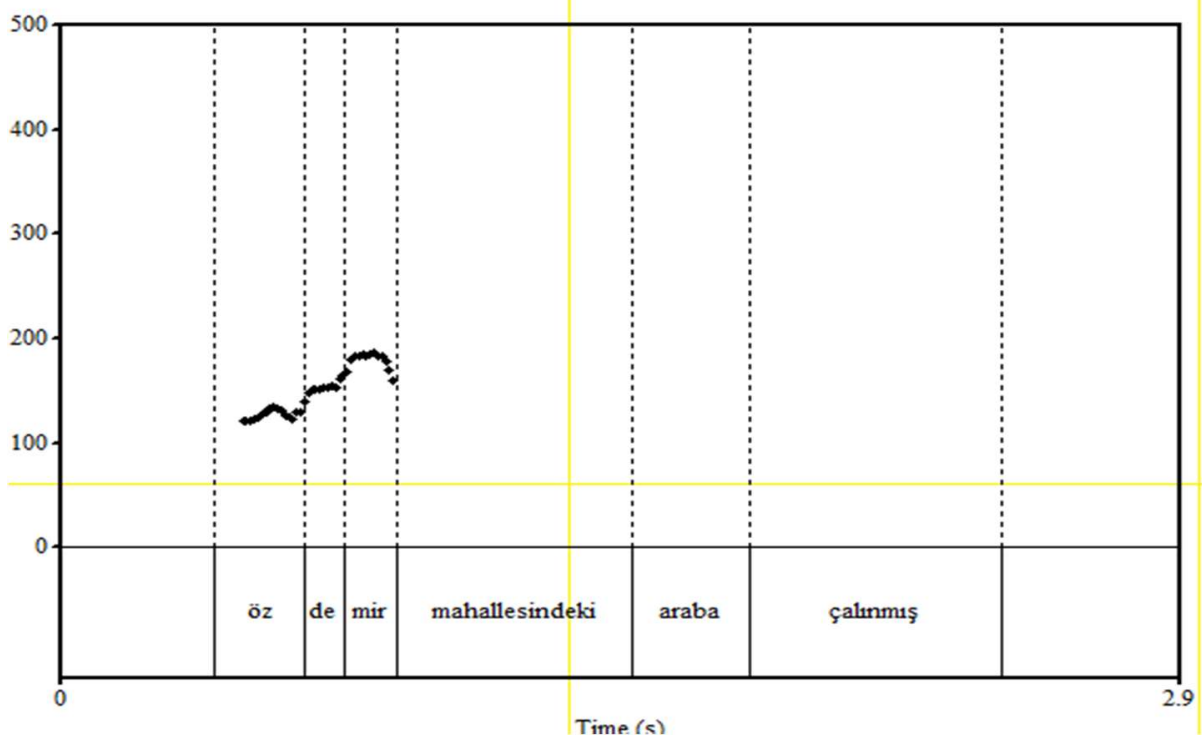

Şekil 7. “Özdemir” sözcüğünün yer adı olarak kullanımına ait vurgu spektrogramı görüntüsü

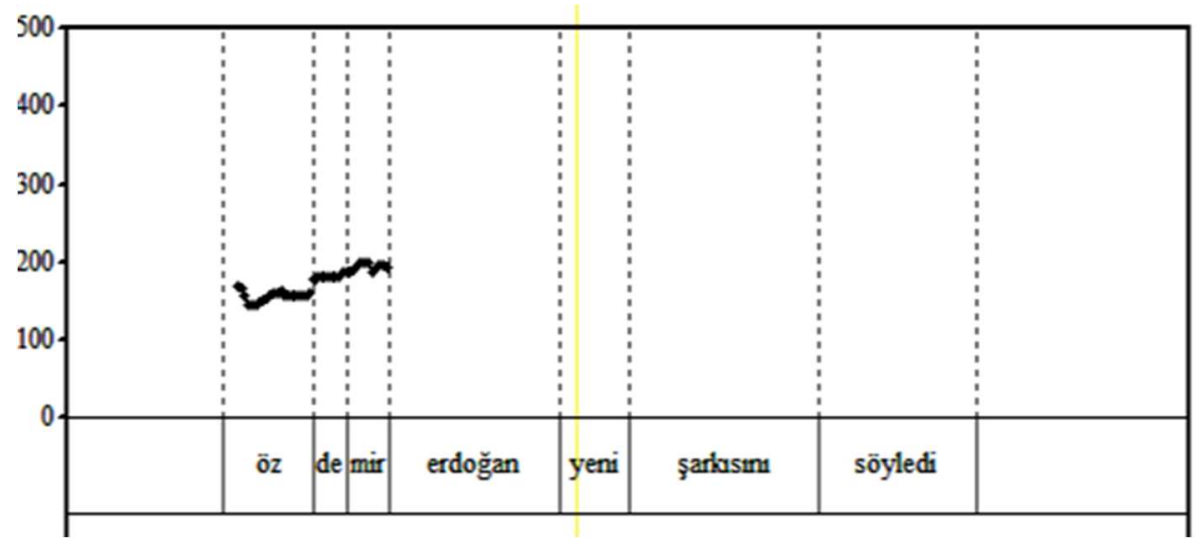

Şekil 8. “Özdemir” sözcüğünün kişi adı olarak kullanımına ait vurgu spektrogramı görüntüsü

6. Hem tamlama hem de birleşik sözcük oluşturan "tepe göz" ve "tepegöz" sözcükleri cümle içerisinde "tepegöz yansıtmıyormuş" ve "onu masalda en çok Tepegöz korkutmuş" kullanılmıştır. İlki yansıtma cihazını tanımlarken ikincisi özel bir ad olan masal kahramanını ifade etmektedir. Vurgununilkinde “göz” sesleminde ikincisinde ise “-pe” sesleminde olduğu görülmektedir. 

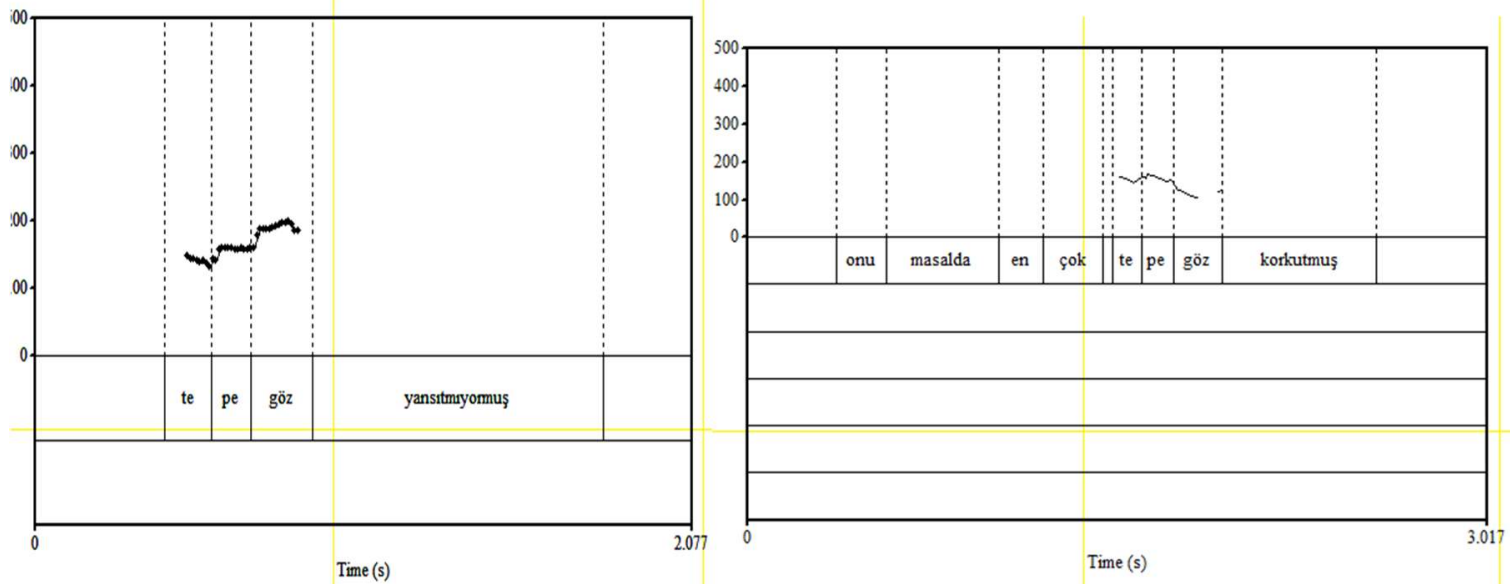

Şekil 9. “Tepegöz” ve “tepegöz” sözcüklerine ait vurgu spektrogram görüntüleri

\section{Sonuç}

Yukarıda verilen örneklerde olduğu gibi hem tamlama oluşturulabilen hem de tamamen bağımsız bir varlık adı oluşturmuş birçok sözcük kaydı alınmıştır. Buna göre tamlama oluşturabilen birçok söz öbeğinin, birleşik sözcük olarak nitelendirildiği şekillerindeki vurgularının tıpkı tamlamada olduğu gibi ilk sözcügün son sesleminde olduğu görülmüştür. Bununla birlikte tamlama olarak kullanımlarındaki ikinci sözcükte bulunan ikincil vurgunun birleşik sözcük olarak kullanımında tamlamadaki kadar düzenli bir biçimde kullanılmadı̆̆ı tespit edilmiştir. Yani "duvar saati”, "çamaşır makinesi" tamlamalarında vurgu birincil ve ikincil olarak tamlamayı oluşturan ilk sözcügün son sesleminde (birincil vurgu -var ve -şır seslemlerinde), ikincil vurgu da ikinci sözcüklerin son seslemlerinde ( ikincil vurgu -ti ve -si) bulunduğu gibi birleşik sözcüklerde bu ikincil vurgunun ikinci sözcükteki kullanımı süreklilik göstermemektedir.

Birleşen sözcüklerin ilk sözcüğü tek seslemden oluşmuşsa vurgu tek ve o seslem üzerinde bulunmaktadır (yüzbaşı, birçok, beştaş gibi sözcüklerde vurgu ilk seslem olan yüz-, bir- ve beş- seslemlerindedir). Birleşen sözcüklerin ilk sözcüğü birden fazla seslemden oluşuyorsa vurgu ilk sözcügün son sesleminde bulunmaktadır ( ayşekadın, civanperçemi, karafatma gibi sözcüklerde vurgu: -şe, -van, -ra seslemlerindedir).

Birleşim sırasında anlamca da birleşmiş böylelikle sözcük vurgusu taşıyan birleşik sözcükler de bulunmaktadır. "karabasan" sözcüğü bunlardan biridir. Bu sözcükte vurgu tek ve -san seslemindedir.

Tüm bu verilerden hareketle birleşik sözcüklerin vurgu görünümlerinin sesbilim, sözdizim olarak birbütünlük gösterseler de anlam bakımından bazı sözcüklerin zihinde henüz birleşmediği vurgu tespitlerinde görülmüştür. Bu durum da vurgunun yerinin her birleşik sözcük için aynı yer ve durumda olmadığını işaret etmektedir.

\section{Kaynakça}

Aktaş, E. (2015). Türkçe Alıntı Sözcüklerde Vurgu Görünümleri. Yayımlanmamış Yüksek Lisans Tezi. Ankara: s.4.

Banguoğlu, T. (1959). Türk Grameri Birinci Bölüm Sesbilgisi. Ankara: TDK.

Bolınger, D. (1958). Stressand Information. American Speech. Say1: 33. 5-20. 
Çürük, Y. (2017). Türkçede Birleşik Sözcükler (İsimler). Yayımlanmamış Doktora Tezi. Ankara.

Demircan, Ö. (1975). “Türk Dilinde Vurgu, Sözcük Vurgusu”.Türk Dili, s.284-290.

Demircan, Ö. (1977). “Bileşik Sözcük ve Bileşik Sözcüklerde Vurgu”.TDAY-Belleten, s.263-275.

Ergenç, İ. (1989). Türkiye Türkçesinin Görevsel Sesbilimi. Ankara: Engin Yayınları.

Ergenç, İ. (2002). Konuşma Dili ve Türkçenin Söyleyişs Sözlüğ̈̈. İstanbul: Multılingual.

Hayes, B. (1995). Metrical Stress Theory Principles and Case Studies. London and Chicago: The Unıversity Of Chicago Press.

Klatt, D. (1975). "Vowel Lengthening is Syntactically Determined in a Connected Discourse," Journal of Phonetics 3, 129-40.

Levi, S. (2002). Intonation in Turkish: the realization of noun compounds and genitive possessive NPs. Ms. University of Washington.

Özsoy, S. (2004). Türkçenin Yapısı-I Sesbilim. İstanbul: Boğaziçi Yay.

Peterson, G. E. (1958) "SomeObservations on Speech," QuarterlyJournal of Speech 44, 402-12

Stetson, R. H. (1928).Motor Phonetics, North Holland, Amsterdam. [2 ${ }^{\text {nd }}$ edition 1951; republished 1988 withcommentaryby J. A. Scott Kelsoand Kevin G. Munhall, Little, Brown and Company, Boston.]

Üçok, N. (1951).Genel Fonetik. Ankara: Multilingual.

Wightman, C,vd. (1992) "Segmental Durations in theVicinity of Prosodic Phrase Boundaries," Journal of the Acoustical Society of America 91,1707 -17. 